\title{
Empowering Disaster Mitigation Learning With E- Books in The Disaster School (SSB) Yogyakarta City
}

\author{
Siti Anafiah ${ }^{1}$, Shanta Rezkita ${ }^{2}$ \\ anafiahs@yahoo.com ${ }^{1}$, shanta.rezkita@ustjogja.ac.id.id ${ }^{2}$ \\ 1,2 Universitas Sarjanawiyata Tamansiswa, Yogyakarta, Indonesia
}

\begin{abstract}
This study aims to (1) describe the implementation of disaster mitigation e-books in learning at the Yogyakarta City Disaster Preparedness (SSB). (2) To find out the obstacles in implementing disaster mitigation e-books in learning activities at the Yogyakarta City Disaster Preparedness School (SSB). This research is a qualitative descriptive study. The study population was 90 schools. The research sample consisted of 3 schools which were proclaimed as SSB, including: SDN Bangunrejo 1, SDN Bangunrejo 2, and SDN Baluwarti. This sampling technique uses purposive sampling technique. Data collection techniques using interviews, observation, and documentation. Data analysis uses the Miles and Huberman models, namely data collection, data reduction, data presentation, and conclusions. The results of the study can be seen that disaster mitigation ebooks is implemented in learning activities. This study also found obstacles in implementing disaster mitigation e-books in learning activities at the Yogyakarta Disaster Preparedness School (SSB), including infrastructure that still needs improvement, media and learning resources, and integration of disaster mitigation in the curriculum and learning.
\end{abstract}

Keywords: Disaster mitigation; Learning; E-books

\section{Introduction}

Various natural disasters that have been and will occur are homework for all elements of society that must be addressed immediately and find a solution. Various knowledge and efforts in disaster mitigation education need to be considered and implemented. Disasters cannot be prevented, but casualties can be minimized if residents have early preparedness for natural disasters.

The introduction of disaster alert can be done in various ways. Schools are one source of knowledge transformation regarding early preparation strategies for natural disasters for students. Disaster mitigation can not only be done with hardware, such as an early warning system. Software such as science is equally important. This software has the urgency to be disseminated immediately. Science can be used as a medium for disaster mitigation to minimize losses.

Based on Minister of National Education Circular (SE) No.70a / SE / MPN / 2010 concerning Mainstreaming Disaster Risk Reduction in Schools, the Minister of National Education called on all Governors, Regents and Mayors in Indonesia to organize disaster management in schools through 3 things: 1 ) empowering the institutional role and ability of the school community; 2) Integration of DRR into the curriculum of formal education units, both intra and extracurricular; and 3) Building 
partnerships and networks between parties to support the implementation of DRR in schools.

Educational institution-based disaster mitigation efforts are still difficult to develop. The reason is, in the last two years there have been three educational institutions at the elementary school level that have been successfully declared as Disaster Preparedness Schools (SSB). Even though the number of elementary schools in Yogyakarta City reached 90 schools. According to the Head of the Yogyakarta City Education Office, Edy Heri, it was not easy to launch a disaster preparedness school. Besides having to map the potential disasters in the school area, readiness of facilities such as human resources and school curriculum is also absolutely necessary. Preparation for planning a disaster prepared school can take one year. This is because all subjects taught according to the curriculum must be integrated with disaster preparedness. The role of teachers is also very important in incorporating disaster preparedness values in various media and learning materials [1].

Based on the results of school observations proclaimed as Disaster Preparedness Schools (SSB) in the city of Yogyakarta, including Bangunrejo 1 Elementary School, Bangunrejo 2 Elementary School, and Baluwarti Elementary School. SDN Bangunrejo 1 and SDN Bangunrejo 2 both schools have been declared SSB since 2015. These two schools are located on the edge of the Winongo River so they have the potential for floods and landslides. Baluwarti Elementary School was only declared as SSB in 2016. SDN Baluwarti is in the middle and has the potential of an earthquake disaster. This can identify that the condition of the environment around the elementary school is different, so that in managing the disaster is also different. The difference will also show that each teacher has experience, knowledge, style, and even different views in teaching that integrate with disaster preparedness.

The difference in potential disasters in the area requires teachers to be more creative in planning, implementing and evaluating so that learning objectives can be achieved, especially in relation to providing knowledge to students about disaster mitigation. In addition, all subjects taught in accordance with the curriculum must be integrated with disaster preparedness. Teachers must include the values of preparedness to face disasters in various media and learning materials.

There are several studies that can have reviewed disaster mitigation. Else Liliani (2008) examines the use of children's literature as a medium for disaster mitigation. Siti Anafiah (2013) examined the use of children's poetry as a medium for disaster mitigation. Both of these studies are library research studies using a pragmatic approach. The results of both studies that children's literature and children's poetry can be used as an effective medium to provide understanding to children regarding disaster mitigation. But with the development of technology, there are many ways teachers use it in presenting books, so that not only the printed version. Research results [2] show that students feel comfortable with the presence of electronic books (e-books). When reading e-books they can choose a title with a choice of other facilities such as automatic reversing pages, however they still need a printed book because the most important thing for students is not only in the format but also the settings, characters, and themes of the book. 
Several studies that have examined disaster mitigation have not been implemented in many digital media schools. These studies are only limited to conceptual studies. With the existence of research on the implementation of e-book disaster mitigation in thematic learning in the Disaster Preparedness School (SSB) can directly inculcate disaster mitigation in students through learning activities, so that efforts to ensure early disaster in children are easier and innovative.

Based on these conditions, there was a desire to know how to implement e-book on disaster mitigation in thematic learning in the Yogyakarta City Disaster Preparedness School (SSB). The purpose of this study is (1) to describe the implementation of e-book disaster mitigation in learning at the Yogyakarta City Disaster Preparedness School (SSB). (2) To find out the obstacles in implementing ebook disaster mitigation in learning activities at the Yogyakarta City Disaster Preparedness School (SSB).

\section{Literature Review}

Disaster mitigation is a term used to show all actions to reduce the impact of a disaster that can be done before the disaster occurs, including readiness and long-term risk reduction measures (http://kawasan.bappenas.go.id. Accessed 28 -2-2018). The same thing was stated also by Promonis (1994: 74) that disaster mitigation is a collective term used to cover all activities carried out in anticipating the emergence of a potential event that causes damage, including preparedness and long-term risk reduction measures, both related to known natural and human hazards, and to deal with disasters that actually occur. Disaster forms, both those caused by nature and human failure are earthquakes, floods, volcanic eruptions, soil instability that cause landslides, high winds, technological hazards, and drought and desertification. Some things that can be done to reduce risk include reducing hazards and vulnerabilities, mastering tools and technology and government policies to create a disaster management management system, as well as community-based mitigation that is closely related to the local imperatives of each region [3].

Yogyakarta as one of the 28 regions in Indonesia that are classified as prone to earthquakes and tsunamis. For this reason, mitigation education that is inserted in each subject should be immediately carried out to prepare students or communities for disaster response [4]. As an example of disaster mitigation education or dissaster education in Japan according to Heru Susetyo [5] carried out with the following variety. (1) Giving information to students about correct knowledge about disasters. (2) Providing an understanding of protection systematically. (3) Equipping students through practical tranning how to protect themselves and how they can respond to the disaster accurately and quickly.

As stated by [6] that post-disaster management in Indonesia often experiences obstacles, so the program planned by the central and regional governments has not run optimally. There are several solutions that can be done with this, for example through the education sector. Education can contribute to reducing the impact of disasters in Indonesia. According to [7] Indonesia needs to formulate a disaster 
education curriculum at the primary school level because considering Indonesia's territory is prone to natural disasters. Disaster education can be integrated into certain subjects in elementary school, for example thematic which contains the contents of science, social studies and Indonesian. This integration will certainly increase knowledge to students about disaster preparedness, with the hope that they can foster awareness and then respond to disasters. Learning in elementary schools like this will help the process of disaster mitigation in Indonesia [8].

Learning about disaster mitigation can be through schools, as well as directly to the general public. In order for schools to implement disaster mitigation lessons, it must be explicitly stated in the curriculum. Disaster mitigation material must appear to have basic competencies. Competencies that need to be added to the curriculum are disaster mitigation competencies, both natural disasters, non-natural disasters and social disasters. Natural disaster mitigation competencies such as basic competencies on earthquake mitigation, disaster eruption mitigation, landslides, floods, storms, and so on. Likewise there must be basic competencies regarding social disasters that are eligible to be included in PPKn and religion subjects with competencies related to friendly, polite, tolerant, tolerant, respectful, caring, and others.

\section{Material \& Methodology}

This research is a qualitative descriptive study. The study population was 90 schools. The study sample consisted of 3 schools which were proclaimed as SSB, including: Bangunrejo 1 Elementary School, Bangunrejo 2 Elementary School, and Baluwarti Elementary School. This sampling technique used purposive sampling technique. Data collection techniques using interviews, observation, and documentation. Data analysis used the Miles and Huberman models, namely data collection, data reduction, data presentation, and conclusion drawing.

\section{Results and Discussion}

Implementation of disaster mitigation in integrated partner schools in learning. Learning in schools uses the 2013 curriculum, integrated disaster mitigation materials in the content of the study fields include: Natural Sciences, Indonesian Language, and others.

The learning step in schools related to disaster mitigation activities is the integration into the learning content. The teacher also uses innovative learning models, so that students can understand disaster mitigation material correctly. This can be seen in the following interview fragments.

"In ordinary learning, I invite children to practice disaster simulations by playing, so that they can understand disaster management correctly and happily"

From the interview excerpt above, it can be concluded that learning with disaster mitigation content can be done by the teacher in a fun way, namely learning while playing. By learning while playing, students easily understand how disaster relief is fun. In addition, learning disaster mitigation can also be done by learning outside the classroom. This can be seen in the following quote. 
"My students invited me to get to know the natural surroundings and disaster management with me taking her out of class. I invite them to the river and how to deal with floods and landslides and how to prevent disasters. "

From the fragments above, it can be seen that disaster prevention can be done with a contextual learning model that involves the nature of the students. Students can get to know the river more closely and the danger it causes. With the direct learning model students will better understand the way of disaster management.

Learning outside the classroom by learning and playing is very popular for students. Students can better understand material and implement ways to mitigate disasters. Integration of disaster mitigation material is also carried out in the evaluation of learning. Students are given assignments related to disaster both written and practical tests. For writing, they are working on a number of questions about the contents of science and Indonesian which are about natural and artificial disaster material. Evaluate practices with the way they practice disaster mitigation simply.

Integrating disaster mitigation material is located in the learning tool. In Baluwarti Elementary School there is already a curriculum in relation to mitigation. This can be seen in the following quote.

"Disaster mitigation in elementary schools is already contained in a separate curriculum. Our curriculum was created in 2015, when the school was declared a Disaster Preparedness School. "

In the above quotation, it is explained that the disaster mitigation curriculum at SD Baluwarti has been created since the school was declared a Disaster Preparedness School (SSB). In addition to the curriculum, integrating disaster mitigation also lies in other learning tools, including: Syllabus, lesson plans, materials, and learning media.

At Bangunrejo 1 Elementary School and 2 the implementation of disaster mitigation was integrated into the learning tools, including: Syllabus, lesson plans, materials, and learning media. This can be seen in the following quote.

"In SD Bangunrejo 1 the implementation of disaster mitigation is integrated in RPP, materials, and learning media. In RPP we apply it in learning activities.

This was also carried out by SDN Bangunrejo 2 which integrated disaster mitigation materials into learning tools, namely in RPP, learning media, and learning materials. This can be seen in the following quote.

"Disaster mitigation materials at SD Bangunrejo 2 are integrated in RPP, learning media, and learning materials."

In the above fragments it can be explained that disaster mitigation material at SDN Bangunrejo 2 is integrated in the learning tools. At SD N Bangunrejo 1 and SD $\mathrm{N}$ Bangunrejo 2 there is no separate curriculum on disaster mitigation.

The role of schools in disaster mitigation is quite active. It is also inseparable from the role of committees, parents, and community members. This can be seen in the following quote.

"Here the commitment to disaster management is quite active. Many people participate too. There are several activities, including: joint service to clean the school. Moreover, this school is located on the edge of the river which can be at any 
time flood. Especially now that the talud is broken down, so that school residents must be careful. "

From this fragment it can be seen that disaster management can be done in collaboration with various elements in the community. School residents and communities participate in disaster management in schools, so that disasters can be prevented.

Obstacles in implementing disaster mitigation in the Yogyakarta City Disaster Preparedness School (SSB) include: unavailability of diverse media in schools that can be utilized by teachers, there are only long textbooks that are difficult to understand for students. The teacher is just fixated on the teacher's book and the student's book, lacking in developing it. Some teachers are accustomed to using the lecture learning model, so students get bored and bored of the learning process.

"Here a lot of books contribute to disaster mitigation, but are only stacked in the library because the books are thick and long narrative so students are not interested in reading them."

From these fragments it can be seen that the learning media in the learning process related to disaster mitigation are still limited to long textbooks that are difficult for students to understand. Therefore, the need for innovative media in the form of e-books to teach disaster mitigation material, so that it can be easily understood by students.

The implementation of disaster mitigation at SDN Bangunrejo 1, SDN Bangunrejo 2, and SDN Baluwarti is integrated in learning tools, learning processes, and evaluations. In the learning tools contained in the syllabus, lesson plans, materials, and learning media. In Baluwarti Elementary School, integrating disaster mitigation is already in a separate curriculum created in 2015 after the school was declared a Disaster Preparedness School (SSB). In the learning process, disaster mitigation is contained in the learning content, including: Social Sciences, Science, Indonesian Language, and others. In learning teachers also use innovative learning models so that disaster mitigation materials can be delivered to students easily and fun. Disaster mitigation material is contained in the evaluation of learning. It aims to find out how far students can understand and practice ways to mitigate disasters.

Obstacles in integrating disaster mitigation into learning include: limited and less attractive learning resources so that students are not interested in reading and learning. In addition, some teachers still use lectures in delivering disaster mitigation material so that students are bored and bored during learning.

\section{Conclusion}

Disaster mitigation materials at SDN Bangunrejo 1, SDN Bangunrejo 2, and SDN Baluwarti are integrated in learning, namely in the learning tools, learning process, and evaluation. But it does not involve digital technology, so it still uses the printed version of the book. Obstacles in the implementation of disaster mitigation in schools, among other things the media is less attractive, some teachers still use the lecture 
method in providing disaster mitigation materials, so students are bored and bored in participating in learning.

\section{References}

[1] Sigit, Agus. "BPBD DIY Hanya Mampu Resminya 3 Sekolah Siaga Bencana Pertahun. Kedaulatan Rakyat hlm 9",2016.

[2] Jones, T.\&Brown, C, "Reading Engagement : A Comparison Between EBooks and Traditional Print Books in an Elementary Classroom" vol. 4, no. 2, pp. 5-22, 2011.

[3] Promonis, A. et all, "Mitigasi Bencana (Modul dalam Program Pelatihan Managemen", 1994.

[4] Sahabat Guru Indonesia,"Lampung Rawan Bencana Pendidikan Mitigasi Bencana. http://sahabatguru.wordpress.com. Diakses 3 Maret 2018.

[5] Purwantoro, Suhadi. "Kapan Pembelajaran Mitigasi Bencana akan Dilaksanakan?" Staff.uny.ac.id.

[6] Atika Zahra Rahmayanti, "Peran Desentralisasi Fiskal dalam Manajemen Bencana di Indonesia" Jurnal Ekonomi dan Pembangunan Vol 22, No. 1, 2014.

[7] M. Sofyan al-Nashr A,"Integrasi Pendidikan Siaga Bencana dalam Kurikulum Madrasah Ibtidaiyah. Jurnal Magistra", Volume 6 Nomor 2 Oktober, 2015.

[8] Dwi Hesti Kristiyaningrum, "Disabo Berbasis Komik Sebagai Media Pendidikan Kebencanaan di Sekolah Dasar Peningkatan",Jurnal Dialektika Jurusan PGSD VOL. 7 NO. 2 September, 2017. 